\title{
Characterization of the antiyeast compound and probiotic properties of a starter Lactobacillus plantarum DW3 for possible use in fermented plant beverages
}

\author{
Duangporn Kantachote $^{1} \square \cdot$ Pakorn Prachyakij $^{1} \cdot$ Wilawan Charernjiratrakul $^{1}$ \\ Metta Ongsakul $^{1} \cdot$ Yodsawee Duangjitcharoen $^{2} \cdot$ Chaiyavat Chaiyasut $^{2}$ \\ Teruhiko Nitoda ${ }^{3} \cdot$ Hiroshi Kanzaki $^{3}$ \\ 1 Department of Microbiology, Faculty of Science, Prince of Songkla University, Thailand \\ 2 Department of Pharmaceutical Science, Faculty of Pharmacy, Chiang Mai University, Thailand \\ 3 The Graduate School of Natural Science and Technology, Okayama University, Japan \\ $\triangle$ Corresponding author: duangporn.k@psu.ac.th.com \\ Received February 24, 2010 / Accepted April 30, 2010 \\ Published online: September 15, 2010 \\ (C) 2010 by Pontificia Universidad Católica de Valparaíso, Chile
}

\begin{abstract}
Lactobacillus plantarum DW3 produced antifungal compounds that inhibited the growth of Rhodotorula mucilaginosa DKA, contaminating yeast in fermented plant beverages (FPBs) and various potential human pathogens. Phenyllactic acid (PLA) identified by gas chromatography- mass spectrometry (GC-MS) was produced at 31 $\mathrm{mg} / \mathrm{L}$ PLA in MRS medium and $5 \mathrm{mg} / \mathrm{ml}$ inhibited growth of the target yeast in vitro by $90 \%$. Other inhibitors were also present but not specifically identified. Results of in vitro tests showed that DW3 also had probiotic properties as it survived various human biological barriers resistance to $\mathrm{pH} 3$, bile salts, growth without vitamin $\mathrm{B}_{12}$ and the presence and absence of oxygen. Its inhibitory effect against foodborne pathogenic bacteria and spoilage organisms was higher than that found for a commercial strain Lactobacillus casei R. An acute oral toxicity test on ICR mice at a high single dose of either $10^{9}$ and $10^{12}$ cells per mouse for 14 days showed that DW3 had no adverse effect on the general health status and there was no evidence of bacteremia. Mice fed DW3 had a reduced weight gain compared to the control. No significant difference $(p>0.05)$ was found for the spleen weight index (SWI) among the treatment and control groups whereas there was a significant difference $(p<0.05)$ for the liver weight ratio (LWR) in a group fed with $10^{12}$ cells per mouse when compared with the control group.
\end{abstract}

Keywords: fermented plant beverage, Lactobacillus plantarum, phenyllactic acid, probiotics, Rhodotorula mucilaginosa, weight control 


\section{INTRODUCTION}

Fermented plant beverages (FPB or FPBs) are a traditional household product in Thailand. They are easily prepared by mixing plant material (cereals, fruits or vegetables) with sugar or honey and water in the proportions of 3: 1: $10(\mathrm{w} / \mathrm{w} / \mathrm{v})$ and are incubated for 1-3 months with a restricted air supply (Kantachote and Charernjiratrakul, 2008a). These FPBs are nonalcoholic being produced by lactic acid bacteria ( $L A B)$ even though yeast contamination is frequently found in the finished product (Prachyakij et al. 2007; Kantachote and Charernjiratrakul, 2008a). They are considered to be a novel functional food product and have been recently approved as a local product by the Thai Industrial Standards Institute, Ministry of Industry.

Contaminating yeasts that are frequently found in FPBs are Rhodotorula sp., Pichia sp., Hansenula sp., Saccharomyces sp. and Candida sp. (Prachyakij et al. 2007). Our previous studies have shown that using starter LAB cultures such as DW3 improved the quality of the finished FPB products (Kantachote and Charernjiratrakul, 2008b; Prachyakij et al. 2008). However, an antiyeast compound produced by our isolate DW3 should be identified.

FPBs provide nutrients and can also provide antimicrobial compounds that originated from the raw materials used or as metabolites from the LAB itself (Kantachote and Charernjiratrakul, 2008a and 2008b). In addition, a probiotic LAB could be used as a starter cultures just as happens in the dairy industry. Many research workers have investigated probiotic lactobacilli e.g. (Reid, 1999; Vinderola and Reinheimer, 2003). Recently, the use of the probiotic Lactobacillus plantarum has been reported in food

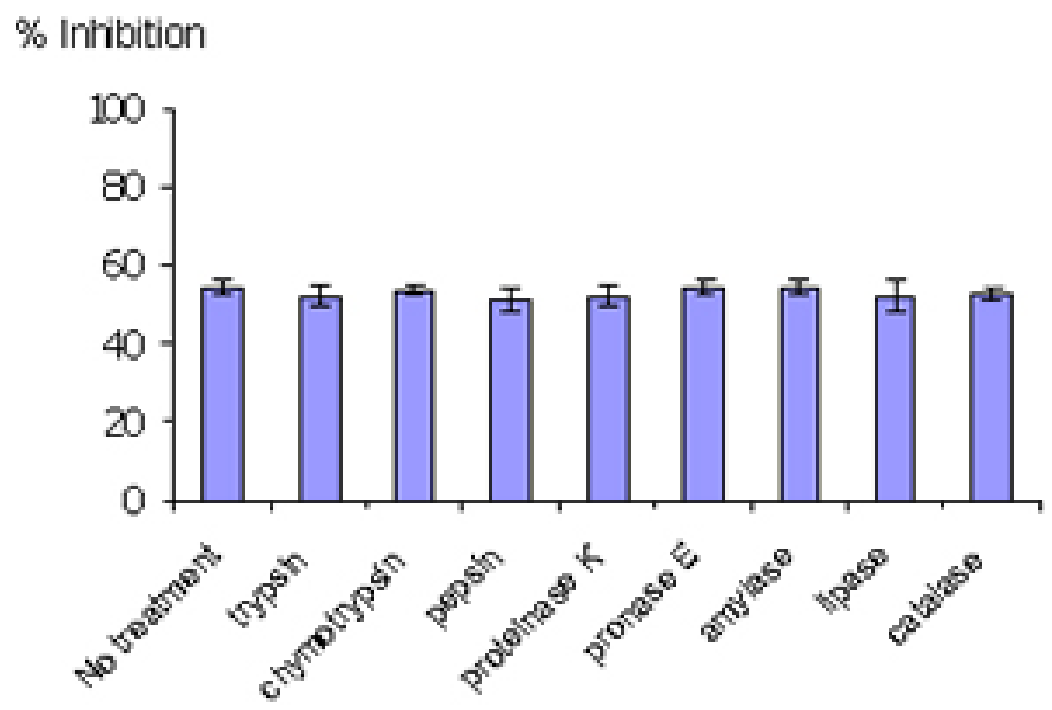

Fig. 1 Effect of enzymes on antifungal activity of 10X FDS, pH 3.6 produced by $L$. plantarum DW3 against growth $R$. mucilaginosa DKA. Each error bar indicates standard deviation $(n=3)$. 
not containing milk or milk products (Molin, 2001; Goossens et al. 2006; Qin et al. 2007). Starter cultures could also be used in order to improve the quality of FPBs, by controlling yeasts in the finished products and to give beneficial properties to consumers. Therefore, a starter culture of $L$. plantalum DW3 previously isolated in our laboratory was studied for its probiotics properties in addition to characterizing its antiyeast metabolite.

\section{MATERIALS AND METHODS}

Preparation of cell free concentrated supernatant (Freeze dried supernatant: FDS) $L$. plantarum DW3, isolated from a fermented seaweed (Gracilaria fisheri) in our laboratory was selected as it has been shown to inhibit various food borne pathogens and produces antiyeast compounds (Prachyakij et al. 2007; Prachyakij et al. 2008). The isolate DW3 was inoculated into MRS broth and incubated at room temperature for $24 \mathrm{hrs}$, then adjusted to $1.5 \times 10^{8} \mathrm{cells} / \mathrm{ml}$ by dilution to $0.5 \mathrm{McF}$ arland units. A $2 \%$ inoculum was added to a $400 \mathrm{ml}$ MRS broth and incubated at room temperature $(28 \pm$ $3^{\circ} \mathrm{C}$ ) for $48 \mathrm{hrs}$ without shaking. A cell free supernatant was obtained by centrifugation at $12,000 \mathrm{rpm}$ (Sorvall RC 5C Plus) for $15 \mathrm{~min}$ and then filtered through a $0.45 \mu \mathrm{m}$ cellulose acetate filter and finally concentrated by freeze drying. A 10-fold concentration of the freeze dried supernatant (10X FDS) was prepared and was sterilized by filtration through a $0.45 \mu \mathrm{m}$ cellulose acetate filter prior to use.

\section{Antiyeast assay}

The isolate DW3 is able to inhibit a variety of yeasts such as Issatchenkia ocidentalis DKB, Pichia membranifaciens DKC, Pichia anomala DKD and R. mucilaginosa DKA (our preliminary study). However, R. mucilaginosa DKA was selected as a target yeast because it is the most common yeast contaminant in the final FPBs (Prachyakij et al. 2007). This yeast was also isolated in our laboratory and the microtiter plate well method according to Magnusson et al. (2003) was used for testing the antiyeast activity of DW3. Briefly, $100 \mu \mathrm{l}$ of malt extract broth containing $10^{4}$ yeast cells per $\mathrm{ml}$ were added to each well of a microtiter plate. $100 \mu \mathrm{l}$ of test samples (i.e. 10X FDS, water and EA fractions see section GC-MS) were transferred to the corresponding wells and incubated at $30^{\circ} \mathrm{C}$ for $48 \mathrm{hrs}$ while $10 \mathrm{X}$ MRS served as a negative control. The yeast growth was measured by a microplate reader at a wavelength of $550 \mathrm{~nm}$. The growth inhibition was calculated by comparison with the negative control of $10 \mathrm{X}$ MRS that showed no inhibition. This indicates that bioactive compounds in the samples tested are able to inhibit the target yeast.

\section{Enzyme treatment of 10X FDS}

In order to investigate the possibility that the antiyeast compounds were proteins, lipids or carbohydrate compounds, the 10X FDS sample was treated with the following enzymes at a final concentration of $0.1 \mathrm{mg} / \mathrm{ml}$; lipase in $0.05 \mathrm{M} \mathrm{Tris-} \mathrm{HCl}(\mathrm{pH}$ 8.0) with $0.01 \mathrm{M} \mathrm{CaCl}_{2}$, a-chymotrypsin in $0.05 \mathrm{M}$ Tris- $\mathrm{HCl}(\mathrm{pH} 8.0)$, trypsin in $0.05 \mathrm{M}$ Tris-HCL (pH 8.0), pepsin in $0.2 \mathrm{M}$ citrate (pH 6.0), pronase $\mathrm{E}$ in $20 \mathrm{mM}$ Tris- $\mathrm{HCl} \mathrm{pH}$ (7.8), proteinase $\mathrm{K}$ in $1 \mathrm{M} \mathrm{NaOH}(\mathrm{pH}$ 6.5) and amylase in $1 \mathrm{M} \mathrm{NaOH}(\mathrm{pH} 6.5)$. Catalase in $10 \mathrm{mM}$ potassium phosphate $\left(\mathrm{pH}\right.$ 7.0) was used to test for $\mathrm{H}_{2} \mathrm{O}_{2}$. All these solutions were filter-sterilized through $0.22 \mu \mathrm{m}$ filters and then added to the 10X FDS $(\mathrm{v} / \mathrm{v}, 1 / 1)$. The 10X MRS was also treated with the various enzymes and immediately 
sampled for use as a negative control whereas the positive control was a 10X FDS without addition of enzymes. The treatments and positive controls were incubated at $37^{\circ} \mathrm{C}$ for $1 \mathrm{hr}$, except for the treatments and control containing trypsin, a-chymotrypsin and catalase that were incubated at $25^{\circ} \mathrm{C}$ (Magnusson and Schnurer, 2001). Before evaluating the antiyeast activity, the $\mathrm{pH}$ of the supernatants was readjusted to the initial $\mathrm{pH}$ value 3.6 as this was the final $\mathrm{pH}$ of the cell free culture fluid. The remaining antiyeast activity was determined by the microtiter plate well method as described above.

\section{High performance liquid chromatography (HPLC)}

A rapid method of HPLC (Armaforte et al. 2006) was used to separate the antiyeast compounds in the cell free culture medium. The R-HPLC, was equipped with a quanternary pump, diode array detector set at $210 \mathrm{~nm}$, a Hypersil ODS column C18 $\mathrm{RP}(250 \times 4.0 \mathrm{~mm}, \mathrm{HP}$, particle size $5 \mu \mathrm{m})$ and run at room temperature. The filtered culture fluid was fractionated using a linear gradient of $25 \%$ acetronitrile in $75 \%$ water (pH 3) (at 0-3.0 min and a flow rate of $1 \mathrm{ml} / \mathrm{min}$ ) up to $50 \%$ acetronitrile in $50 \%$ water

Table 1. Comparison of probiotic properties between Lactobacillus plantarum DW3 and the commercial probiotic Lactobacillus casei R.

\begin{tabular}{|c|c|c|}
\hline Probiotic properties & DW3 & $\mathbf{R}$ \\
\hline Growth at $0.15 \%$ bile salt & + & + \\
\hline Growth at $0.30 \%$ bile salt & + & + \\
\hline Growth at $\mathrm{pH} 2$ & - & - \\
\hline Growth at $\mathrm{pH} 3,4,5$ & + & + \\
\hline Growth at $\mathrm{pH} 8$ & + & - \\
\hline Growth at $\mathrm{pH} 9$ & - & - \\
\hline Oxygen effect on growth & No & No \\
\hline Hydrophobicity $(\% \pm \mathrm{SD})$ & $10.77 \pm 0.05$ & $11.79 \pm 0.23$ \\
\hline Utilization of protein & + & + \\
\hline Utilization of starch & + & - \\
\hline Utilization of lipid & - & - \\
\hline Vitamin B12 requirement & - & - \\
\hline Growth in SPY $2^{1}$ and MRS & $+(r>0.8, p<0.05)$ & $+(r>0.8, p<0.05)$ \\
\hline Doubling time (min) in SPY2 & 59 & 71 \\
\hline Antibiotic susceptibility test ${ }^{2}$ & $\begin{array}{c}\text { Resistance to VC, BC, } \\
\text { GT, KC, ST, NF, PB }\end{array}$ & $\begin{array}{c}\text { Resistance to VC, BC } \\
\text { GT, KC, ST, NF, PB }\end{array}$ \\
\hline
\end{tabular}

No $=$ No significant difference $(p>0.01)$ between growth with or without oxygen present; SD = standard deviation of three determinations..$^{1}$ Animal free medium. ${ }^{2}$ Antibiotics used: VC: vancomycin $(30 \mu \mathrm{g}), \mathrm{BC}$ : bacitracin $(10 \mu \mathrm{g}), \mathrm{GT}$ : gentamycin $(10 \mu \mathrm{g}), \mathrm{KC}$ : kanamycin $(30 \mu \mathrm{g})$, ST: streptomycin $(10 \mu \mathrm{g}), \mathrm{NF}$ : norfloxacin $(10 \mu \mathrm{g})$, PB: polymyxin B (300 $\mu \mathrm{g})$, ampicillin $(10 \mu \mathrm{g})$, cephalothin $(30 \mu \mathrm{g})$, ceftazidime $(30 \mu \mathrm{g})$, chloramphenical $(30 \mu \mathrm{g})$, erythromycin $(15 \mu \mathrm{g})$, penicillin $\mathrm{G}(10 \mathrm{U})$, ceferperazone $(75 \mu \mathrm{g})$, tetracycline $(30 \mu \mathrm{g})$. 
(pH 3) (between 4-6 $\mathrm{min}$ and a flow rate of $1 \mathrm{ml} / \mathrm{min}$ ) and acetronitrile was adjusted to $100 \%$ (between 8-12 $\mathrm{min}$ and a flow rate of $1.3 \mathrm{ml} / \mathrm{min}$ ). Chem Station for LC 3D. Rev.A.10.02 (1757) was used for data acquisition and processing on a personal computer.

\section{Gas chromatography-mass spectrometry (GC-MS)}

An aqueous solution of FDS (1 $/ \mathrm{g} / \mathrm{ml}$ in distilled water) was adjusted to $\mathrm{pH} 2$ using $1 \mathrm{M}$ $\mathrm{HCl}$ then extracted three times with a half volume of ethyl acetate (EA). The EA fractions were separated from the water fraction by centrifugation at $6000 \mathrm{rpm}$ (Sorvall $\mathrm{RC} 5 \mathrm{C}$ Plus) for $10 \mathrm{~min}$ and this provided the EA and water fractions for testing antiyeast activity. Some portion of the organic extract was dried over $\mathrm{Na}_{2} \mathrm{SO}_{4}$ and concentrated in vacuo to obtain an EA fraction suitable for analysis by GC-MS. Trimethylsilyl (TMS) derivatization and GC-MS analysis of the EA fraction were performed according to the method described by Chaves and Gianfagna (2006). Briefly, the dried EA fraction (prepared from $16 \mathrm{mg}$ of FDS) was treated with $50 \mu \mathrm{l}$ of $\mathrm{N}, \mathrm{O}$-bis (trimethylsilyl) acetamide (BSA) at $70^{\circ} \mathrm{C}$ for $15 \mathrm{~min}$ and then injected into the GC column without further purification. GC-MS analyses were performed using a Hewlet Packard (HP) gas chromatograph 5890 series, equipped with an Agilent column DB-1 MS (30 m long, $0.25 \mathrm{~mm}$ i.d., $0.25 \mu \mathrm{m}$ film thickness) using helium as a carrier gas. The oven temperature was set at $70^{\circ} \mathrm{C}$, held for $2 \mathrm{~min}$ and increased to $240^{\circ} \mathrm{C}$ at $10^{\circ} \mathrm{C}$ per min and held for $30 \mathrm{~min}$. The MS source temperature was set at $230^{\circ} \mathrm{C}$. The compounds corresponding to the peaks in the total ion chromatogram were tentatively identified by a library search of the JEOL data system (Lucy version 5.0 software, JEOL). This preliminary identification was confirmed by co-injection of an authentic compound. The amount of phenyllactic acid (PLA) was quantified by using four different concentrations of authentic DL-3-PLA $(4-16 \mu g)$ and $p$ hydroxybenzoic acid was used as the internal standard.

\section{Investigation of probiotic properties in vitro}

The following series of investigations were carried out to provide evidence for the suitability of DW3 to perform as a probiotic when used as a starter culture for FPBs by comparing it with a commercial probiotic strain, Lactobacillus casei (R) (Nagao et al. 2000). Growth in MRS broth supplemented with 0.15 and $0.30 \%$ (w/v) bile salts (Fluka, Switzerland) and also tolerance to $\mathrm{pH}$ values of 2, 3, 4, 5, 8 and 9 was tested (Vinderola and Reinheimer, 2003). Growth as a facultative anaerobe was investigated in MRS broth, with the culture flasks incubated separately in either an anaerobic jar or in an aerobic incubator at $37^{\circ} \mathrm{C}$ for $24 \mathrm{hrs}$. Bacterial growth was measured as turbidity using a spectrophotometer at $\mathrm{OD}_{660 \mathrm{~nm}}$ and all data were analyzed using the pair t-test. Adhesion of the isolate DW3 to hydrocarbons like n-hexadecane was determined for its hydrophobicity according to the method of Vinderola and Reinheimer (2003).

The following agar plates of casein, starch and tributyrin were used to determine the utilization of protein, starch and lipid, respectively with any clear zone around bacterial colonies in each agar medium indicating that the organism had utilized the tested substrates. A requirement for vitamin $B_{12}$ was examined in a vitamin $B_{12}$ assay medium by comparing its growth to that of Lactobacillus delbrueckii subsp. lactis. Additionally, the time course of growth of both cultures in MRS and SPY2 (without animal derived ingredients) (Heenan et al. 2002) were examined and compared statistically as a correlation analysis. 
Antibiotic susceptibility tests to 15 antibiotics in common use (Table 1) were conducted by the agar disc diffusion method, while antibacterial activity against 13 strains of potentially pathogenic food borne bacteria and spoilage bacteria (Table 2) were carried out using the agar spot diffusion method (Kantachote and Charernjiratrakul, 2008a). Bacterial indicators used in this study were provided by the Microbiology Department, Faculty of Science, Prince of Songkla University, Thailand. Antibacterial activity of the isolate DW3 was conducted under 3 conditions according to the methods of Schillinger and Lucke (1989) as follows: production of organic acids and hydrogen peroxide $\left(\mathrm{H}_{2} \mathrm{O}_{2}\right)$ (2\% glucose in MRS agar and incubating under aerobic conditions), production of organic acids but limiting the production of $\mathrm{H}_{2} \mathrm{O}_{2}$ (incubating in an anaerobic jar) and limiting the production of both organic acids and $\mathrm{H}_{2} \mathrm{O}_{2}(0.2 \%$ glucose in MRS agar and incubating in an anaerobic jar).

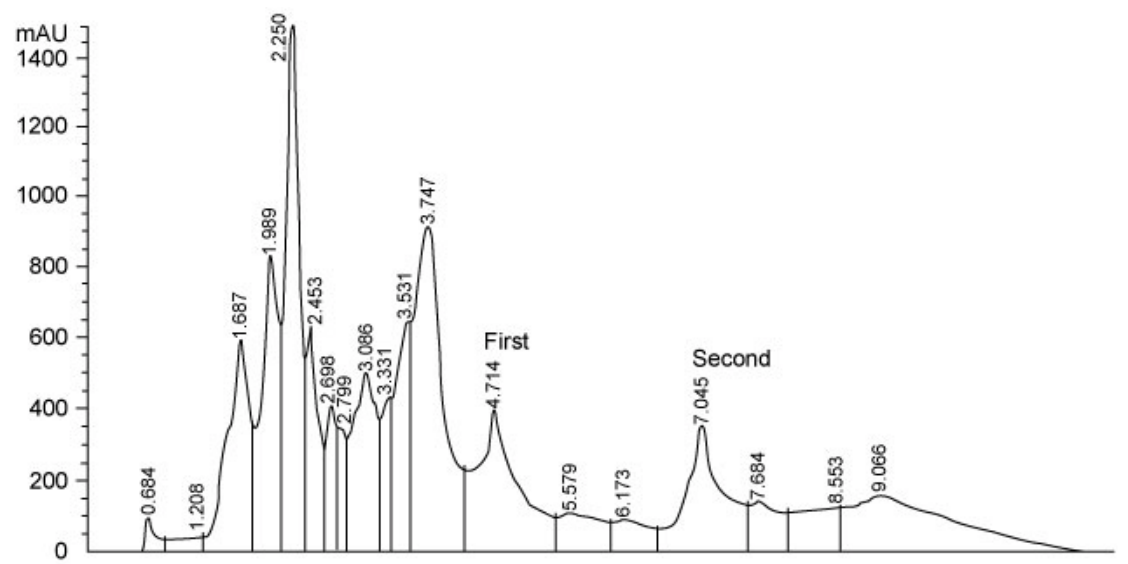

Fig. 2 HPLC profile of the cell free supernatant of Lactobacillus plantarum DW3. Column: Hypersil ODS column C18 RP (250 x $4.0 \mathrm{~mm}$, HP, particle size $5 \mu \mathrm{m})$. Elution: linear gradient from $25 \%$ acetronitrile in $75 \%$ water (at $0-3.0 \mathrm{~min}$, flow rate $1 \mathrm{ml} / \mathrm{min}$ ) to $50 \%$ acetronitrile in $50 \%$ water (in 4-6 min, flow rate $1 \mathrm{ml} / \mathrm{min}$ ) and acetronitrile was adjusted to $100 \%$ (in 8-12 min, flow rate $1 \mathrm{ml} / \mathrm{min}$ ). Detection: diode array detector set at $210 \mathrm{~nm}$.

\section{Safety assessment of $L$. plantarum DW3 in vivo}

The isolate DW3 was cultured in MRS broth at $37^{\circ} \mathrm{C}$ for $18 \mathrm{hrs}$, cells were then centrifuged at 12,000 rpm (Sorvall RC 5C Plus) for $15 \mathrm{~min}$. Cell pellets were washed twice in phosphate buffer saline (PBS), pH 7.4 and resuspended in PBS to obtain a cell density at approximately $10^{9}$ and $10^{12}$ cells per mouse. Groups of five, 4-5 week old male ICR mice (Mus musculus) weighing 22-24 g were housed in transparent plastic cages. All cages were placed in a room controlled at $24 \pm 2^{\circ} \mathrm{C}, 55 \pm 5 \%$ humidity and a light-dark cycle of 12 hrs throughout the study. Animal experiments were conducted at the Southern Institute Animal Laboratory, Faculty of Science, Prince of Songkla University, Thailand.

In order to assess the safety of the DW3 isolate, a single $150 \mu \mathrm{l}$ dose of lactobacilli was administered orally to each mouse and one group of 5 mice was fed with sterile PBS to serve as a control set. After feeding, mice were monitored daily for 14 days to 
observe any changes in their activities, behaviour and general health. Individual body weight was recorded daily using a balance. In addition, the feces of mice were collected to enumerate the total numbers of lactobacilli everyday for 14 days. The growth rate (GR) was calculated as \% per day following the formula (GR $=W_{t} / W_{0} X$ $100 / t, W_{t}$ : body weight on the day of measurement, $W_{0}$ : body weight at the beginning and t: day of measurement). On day 14, all mice were sacrificed by cardiac islocation and were bled by cardiac puncture. Blood was used to check and count bacteria for investigation of bacteremia while the liver and spleen were weighed. A spleen weight index (SWI) was performed as the actual spleen weight (mg) divided by the last measured live body weight $(\mathrm{g})$ while the percentage liver weight ratio was expressed as the liver weight $(\mathrm{g}$ ) divided by the body weight $(\mathrm{g})$ multiplied by 100 . One way analysis of variance (ANOVA) followed by Tamhane's T2 was used to compare the results of the probiotic and control groups. Means, standard deviations and significant differences at $p$ value $<0.05$ are presented.

\section{RESULTS AND DISCUSSION}

\section{Characterization of the antiyeast substance}

The 10X FDS produced a 55.3\% inhibition of the growth of the target yeast $(R$. mucilaginosa DKA), in the positive control set without treatment by enzymes (Figure 1). After treatment with various proteases, the full antiyeast activity remained. Similar results were obtained after treatments with amylase, lipase and catalase. The results indicate that the antiyeast components of the FDS from the isolate DW3 were not proteins and were not related to carbohydrate or lipid moieties. In addition, catalase had no effect on the antiyeast activity therefore hydrogen peroxide $\left(\mathrm{H}_{2} \mathrm{O}_{2}\right)$ was not one of the active compounds. Most LAB possess flavoprotein oxidases and NADH oxidase, that enables them to actively produce $\mathrm{H}_{2} \mathrm{O}_{2}$ in the presence of oxygen (Marty-Teysset et al. 2000). However, in this study, the isolate DW3 was grown under static condition with little access to oxygen; therefore, none or little hydrogen peroxide could be produced. To prove that the isolate DW3 may produce antiyeast compounds other than the organic acids such as lactic acid and acetic acid, HPLC was used to test for other antiyeast compounds.

HPLC analysis of the cell free supernatant produced two major peaks at 4.714 and 7.045 min (Figure 2). However, only the first peak had antiyeast activity and the retention time corresponded to phenyllactic acid (PLA). Five $\mathrm{mg} / \mathrm{ml}$ of the first peak showed strong inhibitory activity (88\%) against the growth of the target yeast (data not shown). To confirm the presence of PLA in the culture filtrate, GC-MS analyses were performed. The EA fraction was analyzed by GC-MS after TMS-derivatization with BSA (N, O-bis (trimethylsilyl)-acetamide). The compound corresponding to the peak with retention time of $13.7 \mathrm{~min}(13 \mathrm{~min} 41 \mathrm{sec}$ ) was identified as PLA by comparing its electron ionization (EI)-MS spectrum with that recorded in the mass spectrum library (data not shown). The total ion chromatograms from the GC-MS analysis of the EA fraction and authentic PLA are shown (Figure 3). Apart from PLA, a succinic acid peak with a retention time of $10.0 \mathrm{~min}$ was found in the EA fraction. Production of succinic acid by the isolate DW3 was of interest because it can be a precursor of a variety of chemicals such as 1,4 butanediol, y-butyrolactone, tetrahydrofuran and some biodegradable polymers (Willke and Vorlop, 2004). 
Identifications were also confirmed by co-chromatography with the authentic PLA. The peak area of the compound $\left(t_{R}=13.7 \mathrm{~min}\right)$ in the EA fraction was significantly increased when co-injected with the authentic PLA (data not shown). Besides, the peak for PLA another peak ( $t_{R}=15.3 \mathrm{~min}: 15 \mathrm{~min} 16 \mathrm{sec}$ and $15 \mathrm{~min} 17 \mathrm{sec}$ ) was present in both the EA fraction and the authentic PLA (Figure 3), therefore we suspect that this compound was not a natural component of the FDS. Co-chromatographic analysis obviously indicated that the additional peak observed in both the EA fraction and the authentic PLA was the same compound because a significant increase of this peak area was observed after co-injection (data not shown). Hence, this compound might have been produced from PLA in the derivatization step.

Table 2 Antibacterial activity of Lactobacillus plantarum DW3 and the commercial probiotic Lactobacillus casei $\mathrm{R}$ after $18 \mathrm{hrs}$ of incubation under varying conditions.

\begin{tabular}{|c|c|c|c|c|c|c|}
\hline \multirow[t]{2}{*}{ Pathogens } & \multicolumn{2}{|c|}{$\begin{array}{l}\text { Production of } \\
\text { acids and } \mathrm{H}_{2} \mathrm{O}_{2}\end{array}$} & \multicolumn{2}{|c|}{$\begin{array}{c}\text { Limitation of } \\
\text { only } \mathrm{H}_{2} \mathrm{O}_{2}\end{array}$} & \multicolumn{2}{|c|}{$\begin{array}{l}\text { Limitation of acids } \\
\text { and } \mathrm{H}_{2} \mathrm{O}_{2} \text { production }\end{array}$} \\
\hline & DW3 & $\mathbf{R}$ & DW3 & $\mathbf{R}$ & DW3 & $\mathbf{R}$ \\
\hline $\begin{array}{l}\text { Staphylococcus aureus } \\
\text { ATCC } 25923\end{array}$ & +++ & + & +++ & ++ & + & - \\
\hline $\begin{array}{l}\text { Bacillus cereus ATCC } \\
1778\end{array}$ & +++ & + & +++ & + & + & + \\
\hline $\begin{array}{l}\text { Shigella sonnei PSSCMI } \\
0032\end{array}$ & +++ & ++ & ++ & + & + & - \\
\hline $\begin{array}{l}\text { Shigella flexneri PSSCMI } \\
0035\end{array}$ & +++ & + & +++ & ++ & + & + \\
\hline $\begin{array}{l}\text { Salmonella Typhimurium } \\
\text { PSSCMI } 0035\end{array}$ & ++ & + & + & + & + & - \\
\hline $\begin{array}{l}\text { Salmonella Typhi } \\
\text { PSSCMI } 0034\end{array}$ & +++ & ++ & +++ & + & + & + \\
\hline $\begin{array}{l}\text { Escherichia coli ATCC } \\
25922\end{array}$ & +++ & + & ++ & + & + & - \\
\hline $\begin{array}{l}\text { Escherichia coli O157: } \\
\mathrm{H} 7\end{array}$ & ++ & + & + & + & + & - \\
\hline $\begin{array}{l}\text { Vibrio parahaemolyticus } \\
\text { VP } 4\end{array}$ & +++ & ++ & +++ & + & + & + \\
\hline $\begin{array}{l}\text { Proteus vulgaris PSSCMI } \\
0041\end{array}$ & +++ & ++ & +++ & +++ & + & + \\
\hline $\begin{array}{l}\text { Proteus rettgeri PSSCMI } \\
0044\end{array}$ & ++ & + & +++ & + & + & + \\
\hline $\begin{array}{l}\text { Enterobacter cloacae } \\
\text { PSSCMI } 0040\end{array}$ & ++ & - & ++ & + & + & - \\
\hline $\begin{array}{l}\text { Enterobacter aerogenes } \\
\text { PSSCMI } 0039\end{array}$ & ++ & + & ++ & + & + & + \\
\hline
\end{tabular}

Three replicates were conducted in this study and the inhibition was graded by inhibition zone using the following scales; $+++=$ very strong $\geq(10 \mathrm{~mm}),++=$ strong $(7-9 \mathrm{~mm}),+=$ moderate $(<7 \mathrm{~mm}),-=$ poor $(\mathrm{no}$ inhibition zone). 


\section{Role of PLA as an antimicrobial compound}

It has long been known that $L A B$ play an important role in fermented foods as they produce a variety of compounds such as organic acids, hydrogen peroxide and bacteriocins that can control spoilage organisms and also potential pathogens (Messens and De Vuyst, 2002; Simsek et al. 2006; Tharmaraj and Shah, 2009). Among the bioactive compounds produced by LAB, PLA is a novel antimicrobial compound due to its ability to control both Gram positive bacteria and Gram negative bacteria, a wide range of fungi and some mycotoxigenic species (Lavermicocca et al. 2003, Prachyakij et al. 2008). Therefore, PLA is a biopreservative that could be used instead of propionic acid and its salt in bakery products. It is well recognized that PLA is produced by some LAB i.e. L. plantarum 21B and L. plantarum MiLAB393 (Lavermicocca et al. 2000; Strom et al. 2002) and in this study we have shown that PLA was also produced by L. plantarum DW3.

The PLA content was determined by GC-MS analysis using $p$-hydroxybenzoic acid as an internal standard. The PLA content was found to be $0.85 \mu \mathrm{g} / \mathrm{mg}$ FDS, namely 31 $\mathrm{mg} / \mathrm{L}$ of supernatant. Compared to the finding of Li et al. (2007), 60 of 112 strains of LAB produced between 16-61 mg/L PLA, L. plantarum DW3 is therefore a moderate producer of PLA. All forms of pure PLA (D-, L-, DL-PLA) require $5 \mathrm{mg} / \mathrm{ml}$ to produce $90 \%$ inhibition of the growth of $R$. mucilaginosa (data not shown). Table 3 shows that $44 \mathrm{mg} / \mathrm{ml}$ of pure FDS gave a $92.1 \%$ inhibition of growth of the target yeast, whereas the concentration of PLA contained in the FDS was only $0.031 \mathrm{mg} / \mathrm{ml}$. Therefore, it can be concluded that PLA from the isolate DW3 was not the main antiyeast compound in the FDS. Additionally, results in Table 3 also show that the antiyeast activity of FDS was higher than that found in EA and the water fractions. This means that there are antiyeast compounds other than PLA in the FDS. In addition, the isolate DW3 has proved to be a successful starter culture to control contaminating yeasts in a fermented seaweed beverage (Prachyakij et al. 2008).

\section{Detection of probiotic properties in vitro}

Both the isolate DW3 and a commercial probiotic strain R, grew with both $0.15 \%$ and $0.30 \%$ bile salts in a modified MRS medium (Table 1). In addition, $90 \%$ of both strains survived a pH of 3 and 4 during a $3 \mathrm{hrs}$ incubation period. The DW3 isolate also had a $50 \%$ survival at $\mathrm{pH} 8$, but the $\mathrm{R}$ strain died. However, neither of them grew at $\mathrm{pH} 2$ or 9. Biological barrier tests are required to prove a bacterium has probiotic potential because normally they must survive transit through the acidic conditions of the stomach and bile in the intestine (Vinderola and Reinheimer, 2003). In addition, ability to survive in the absence or presence of oxygen is another human physiological barrier that many possible probiotic bacteria in commercial products fail (Shah et al. 2000). Fortunately, both strains tested showed no significant differences $(p<0.01)$ in their growth in the presence or absence of oxygen. Again, the hydrophobicity of both strains tested was quite similar at 10.77 and $11.79 \%$ for the strain DW3 and the commercial probiotic strain, respectively. Other probiotic strains such as $L$. casei and Lactobacillus rhamnosus, have hydrophobicity values that range from 10.9 to $24.1 \%$ (Vinderola and Reinheimer, 2003; Tamang et al. 2009).

Both strains also had no requirement for vitamin B12 as they grew to an $\mathrm{OD}_{660 \mathrm{~nm}}>$ 2.00 in a cobalamin deficient medium. This means that they would be unlikely to compete with the human body for cobalamin. A supply of vitamin B12 is especially important for vegetarians due to its low levels in their foods (Elmadfa and Singer, 

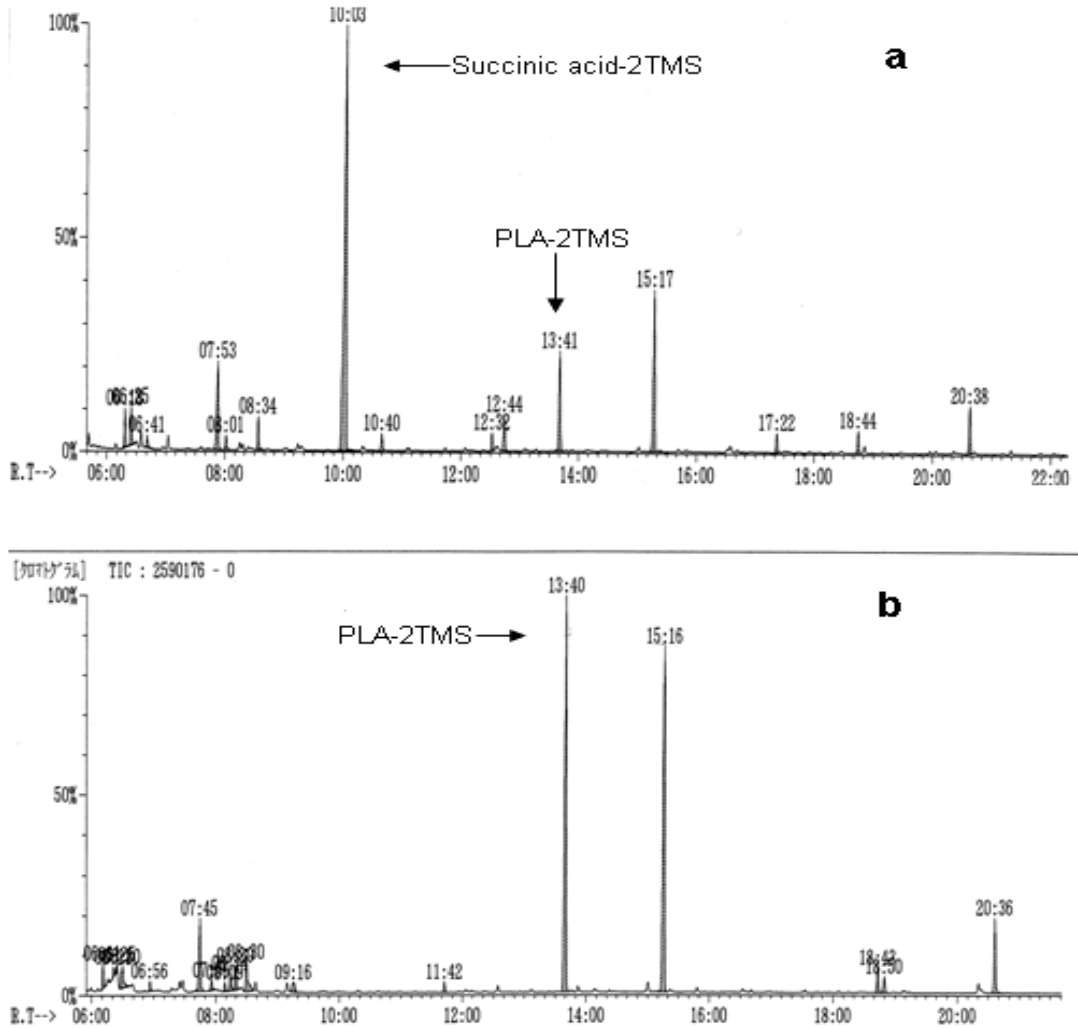

Fig. 3 Total ion chromatograms in GC-MS analysis of EA fraction of Lactobacillus plantarum DW3 (a) and authentic PLA (b).

2009). Some probiotic microbes display an array of enzymes that might be useful for improving human digestion. The DW3 isolate hydrolyzed both protein and starch, but the $\mathrm{R}$ strain hydrolyzed only protein probably because it was isolated from a commercial milk product. Hence, the isolate DW3 may provide more benefit to the human digestive system than the commercial strain R. Comparisons of the time course of growth and the relative viable cell counts between MRS and SPY2 broths showed that both strains had Pearson's correlation coefficients $(r)$ level $>0.8(p<$ 0.05 ). Therefore, the isolate DW3 is suitable for use as a starter culture in any medium containing either animal or plant ingredients. It was also of interest that, the isolate DW3 had a shorter generation time of only 59 min in SPY2 medium compared to 71 min for the R strain. Hence, it is likely that the isolate DW3 can respond more quickly than the R strain to any possible source of substrate.

The antibiotic susceptibility tests showed that both strains were resistant to 7 of the 15 antibiotics tested as follows: $30 \mu \mathrm{g}$ vancomycin, $10 \mu \mathrm{g}$ bacitracin, $10 \mu \mathrm{g}$ gentamicin, $30 \mu \mathrm{g}$ kanamycin, $10 \mu \mathrm{g}$ streptomycin, $10 \mu \mathrm{g}$ norfloxacin and $300 \mu \mathrm{g}$ polymyxin B (Table 1). Results of a clinical trial have indicated that the incidence of antibiotic associated diarrhea and Clostridium difficile associated diarrhea can be reduced after consumption of a probiotic drink containing L. casei, Lactobacillus bulgaricus and 
Streptococcus thermophilus (Hickson et al. 2007). Therefore, co-administration to patients might facilitate a change in the imbalance of the intestinal microflora to become normal.

Table 2 shows that the inhibitory effect of the isolate DW3 against 13 strains of food borne pathogenic bacteria and spoilage bacteria was higher than that found for the commercial strain $\mathrm{R}$ in all conditions tested. One of the important attributes for $\mathrm{a}$ lactobacillus strain to be an effective probiotic organism is that it has antimicrobial activity by producing organic acids, $\mathrm{H}_{2} \mathrm{O}_{2}$ and other inhibitory compounds (Reid, 1999; Ito et al. 2003). Isolate DW3 produces organic acids and other bioactive compounds like PLA. Thus it would be of interest to see if FPBs produced with starting cultures of probiotic bacteria together with some antibiotic would assist in curing some diseases.

\section{Safety assessment of $L$. plantarum DW3 in vivo}

As a safety assessment has been listed as an important criterion for selecting potential probiotic strains prior to being incorporated into food products (Zhou et al. 2000; Bernardeau et al. 2002), a mouse acute oral toxicity safety assay was conducted on the isolate DW3. Fourteen days after force-feeding mice with a very high dose $\approx 10^{12}$ cells per mouse, $3.15 \times 10^{13}$ cells $/ \mathrm{kg}$ ), a high dose $₹ 10^{9}$ cells per mouse, $3.17 \times 10^{10}$ cells $/ \mathrm{kg}$ ) and the control group, there were no detectable differences in behaviour or activity and no diarrhoeal deaths. Also blood samples collected by cardiac puncture showed no viable bacteria on MRS or PCA from any mice. This clearly indicated that isolate DW3 did not exhibit gross acute oral toxicity effects on the general health status, growth and development of the mice tested and it is reasonable to conclude that the isolate DW3 showed no ability to infiltrate to or proliferate in areas outside of the intestines. Generally, adherence and colonization is considered to be an important property of probiotic strains and adherence can be considered to be the first step of colonization (Wold, 2002). In this study, hydrophobicity and a fecal count of lactobacilli were determined to assess the persistence of lactobacilli in mice to ensure that colonization has occurred. It was found that there were no significant differences for the numbers of lactobacilli in feces between the treated groups and control group (9 log cfu/g-10 log cfu/g) (data not shown) throughout the 14 days of the experiment. Results indicate that at least the isolate DW3 persisted in the intestines.

Table 3 Antiyeast activity of Lactobacillus plantarum DW3 in forms of FDS, EA fraction and Water fraction against the growth of Rhodotorula mucilaginosa DKA.

\begin{tabular}{lccc}
\hline Concentration & \multicolumn{3}{c}{ Growth Inhibition (\%) } \\
\hline$(\mathrm{mg} / \mathrm{ml})$ & FDS & EA fraction & Water fraction $^{1}$ \\
350 & 100 & 100 & 100 \\
265 & 100 & 100 & 100 \\
175 & 100 & 100 & 100 \\
90 & 100 & $95.5 \pm 0.5$ & $\mathbf{9 7 . 5} \pm \mathbf{0 . 4}$ \\
44 & $\mathbf{9 2 . 1} \pm \mathbf{0 . 6}$ & $73.9 \pm 2.2$ & $69.3 \pm 1.1$ \\
17.5 & $28.0 \pm 1.8$ & $20.1 \pm 1.3$ & $18.2 \pm 2.3$ \\
9.0 & $19.1 \pm 0.7$ & $12.5 \pm 0.8$ & $10.2 \pm 1.0$ \\
\hline
\end{tabular}

${ }^{1}$ Doses of EA and water fractions are expressed in equivalent mg of FDS.

Each value is the mean percentage of three replicates \pm standard deviation. 
However, after 14 days the growth rate of mice in both groups treated with the isolate DW3 was significantly lower than that found in the control group (Figure 4). However, the weight gain of all groups over the 14 days was within the normal value for mice $(1.28 \pm 0.29 \mathrm{~g}$ in the control group and $0.2 \pm 0.05-0.25 \pm 0.08 \mathrm{~g}$ in the probiotic groups) based on the report of The National Laboratory Animal Center (2007). This control of weight gain in the mice fed with L. plantarum DW3 is similar to that found in our previous work with $L$. plantarum SS2 in mice when there was also a reduced weight gain compared to a control (Duangjitcharoen et al. 2009). Recently, weight management is considered to be an additional positive role for probiotic microbes. For instance, Salminen (2009) reported that there is evidence that specific probiotics have an impact on weight gain and might help to control weight gain for instance during pregnancy. Probiotics might reduce fat storage by changing the intestinal microbiota. Obese subjects harbor more microbes of the phylum Firmicutes whereas lean subjects harbor more bacteroidetes (Ouwehand, 2009). Therefore, probiotics like bifidobacteria and lactobacilli may act by reducing Fermicutes. However, it would seem unrealistic to assume that obesity could be solved by using probiotic bacteria but it would be of interest to explore this possibility.

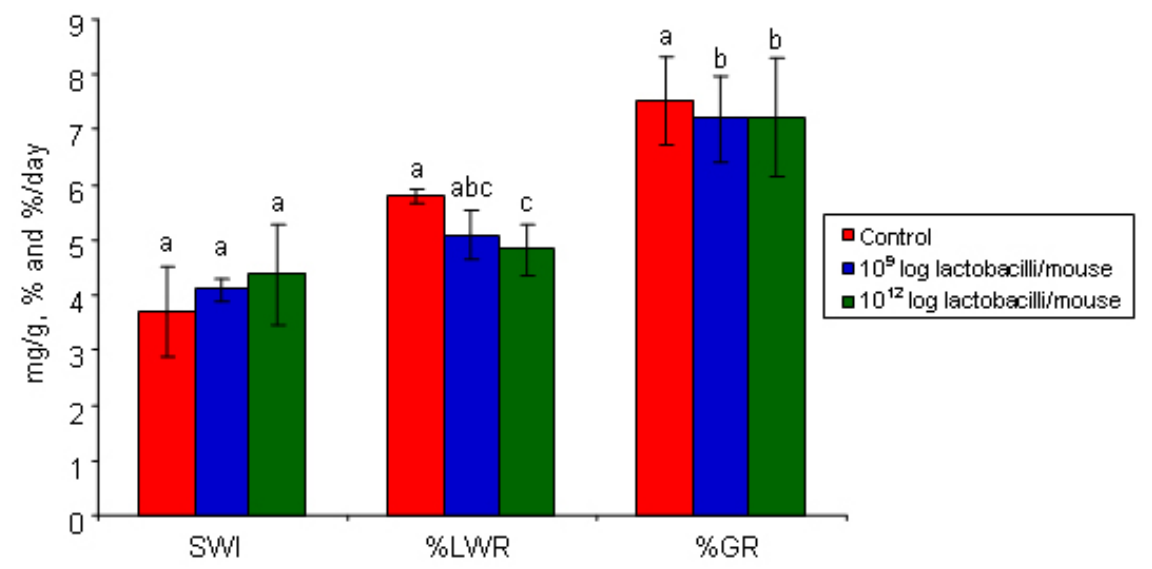

Fig. 4 Spleen weight index, liver weight ratio (\%) and growth rate (\%/day) in mice fed with a single dose of Lactobacillus plantarum DW3 and the control group, phosphate buffer saline (pH 7.4). Different letters above bars indicate significant differences $(p<0.05)$.

Macroscopic examination of the visceral organs in the treated groups and the control group did not reveal any obvious differences in their size or appearance (data not shown). The spleen and liver weight ratios of mice fed with the isolate DW3 and the control groups are shown in Figure 4 . There was no significant difference $(p>0.05)$ in SPI among the mice receiving the bacterium at both levels of cell density in comparison with the control mice that received PBS. The evidence of no change in spleen weights in the treated mice indicates that the isolate DW3 did not cause or induce systemic infections in experimental mice and being non-invasive is likely to be safe for human use. However, a very high dose of the bacterium ( $10^{12}$ cells per mouse) significantly decreased LWR as compared to the control group while there was no statistical difference between the two treated groups $\left(10^{9}\right.$ and $10^{12}$ cells per mouse) (Figure 4). A similar result has been found in rats that received a dietary probiotic with a high fat and high cholesterol content. A significantly decreased liver 
weight was found in contrast to that found using dietary rice bran while the total cholesterol concentration in the serum of the probiotic group was significantly lower than that of the control group (Fukushima and Nakano, 1995).

In conclusion, results in this study indicate that L. plantarum DW3 is a potential probiotic bacterium with an ability to control foodborne pathogens, spoilage organisms and contaminating yeasts in FPBs by producing a number of antimicrobial compounds including organic acids and phenyllactic acid and is likely to be safe for human consumption. Hence, the isolate DW3 is a promising strain to be used as a starter culture for improving the quality of the FPBs and providing significant benefits to the consumers.

\section{ACKNOWLEDGMENTS}

We would like to thank Dr. Brian Hodgson for his suggestions for improving the manuscript and checking the English.

Financial support: This work was supported by National Science and Technology Development Agency (NSTDA), Thailand and the project numbers are CO-B-22-2C-10-483 and CO-B-22-2C18-4801 including the Graduate School, Prince of Songkla University.

\section{REFERENCES}

ARMAFORTE, Emanuele; CARRI, Simone; FERRI, Giovanni and CABONI, Maria Fiorenza. High performance liquid chromatography determination of phenyllactic acid in MRS broth. Journal of Chromatography A, October 2006, vol. 1131, no. 1-2, p. 281-284. [CrossRef]

BERNARDEAU, Marion; VERNOUX, Jean Paul and GUEGUEN, Micheline. Safety and efficacy of probiotic lactobacilli in promoting growth in post-weaning Swiss mice. International Journal of Food Microbiology, July 2002, vol. 77, no. 1-2, p. 19-27. [CrossRef]

CHAVES, Fabio C. and GIANFGNA, Thomas J. Necrotrophic phase of Moniliophthora perniciosa causes salicylic acid accumulation in infected stems of cacao. Physiological and Molecular Plant Pathology, July-September 2006, vol. 69, no. 1-3, p. 104-108. [CrossRef]

DUANGJITCHAROEN, Y.; KANTACHOTE, D.; ONGSAKUL, M.; POOSARAN, N. and CHAIYASUT, C. Potential use of probiotic Lactobacillus plantarum SS2 isolated from a fermented plant beverage: safety assessment and persistence in the murine gastrointestinal tract. World Journal of Microbiology and Biotechnology, February 2009, vol. 25, no. 2, p. 315-321. [CrossRef]

ELMADFA, Ibrahim and SINGER, Ingrid. Vitamin B-12 and homocysteine status among vegetarians: a global perspective. American Journal of Clinical Nutrition, May 2009, vol. 89, no. 5, p. 1693s-1698s. [CrossRef]

FUKUSHIMA, Michihiro and NAKANO, Masuo. The effect of a probiotic on faecal and liver lipid classes in rats. British Journal of Nutrition, 1995, vol. 73, no. 5, p. 701-710. [CrossRef]

GOOSSENS, D.A.M.; JONKERS, D.M.A.E.; RUSSEL, M.G.V.M.; STOBBERINGH, E.E. and STOCKBRUUGER, R.W. The effect of a probiotic drink with Lactobacillus plantarum $299 \mathrm{v}$ on the bacterial composition in faeces and mucosal biopsies of rectum and ascending colon. Alimentary Pharmacology \& Therapeutics, January 2006, vol. 23, no. 2, p. 255-263. [CrossRef]

HEENAN, C.N.; ADAMS, M.C.; HOSKEN, R.W. and FLEET, G.H. Growth medium for culturing probiotics bacteria for applications in vegetarian food products. Lebensmittel-Wissenschaft und-Technologie, March 2002, vol. 35, no. 2, p. 171-176. [CrossRef]

HICKSON, Mary; SOUZA, Aloysius L.D.; MUTHU, Nirmala; ROGERS, Thomas R.; WANT, Susan; RAJKUMAR, Chakravarthi and BULPITT, Christopher J. Use of probiotic 
Lactobacillus preparation to prevent diarrhea associated with antibiotics: randomized double blind placebo controlled trial. British Medical Journal, July 2007, vol. 335, no. 7610, p. 80-83. [CrossRef]

ITO, Ayano; SATO, Yuki; KUDO, Susumu; NAKAJIMA, Hajime and TOBA, Takahiro. The screening of hydrogen peroxide-producing lactic acid bacteria and their application to inactivating psychrotrophic food-borne pathogens. Current Microbiology, September 2003, vol. 47, no. 3, p. 231-236. [CrossRef]

KANTACHOTE, Duangporn and CHARERNJIRATRAGUL, Wilawan. Effects of initial air removal methods on microorganisms and characteristics of fermented plant beverages. Pakistan Journal of Biological Science, January 2008a, vol. 11, no. 2, p. 173-180. [CrossRef]

KANTACHOTE, Duangporn and CHARERNJIRATRAKUL, Wilawan. Selection of lactic acid bacteria from fermented plant beverages to use as inoculants for improving the quality of the finished product. Pakistan Journal of Biological Science, November 2008b, vol. 11, no. 22, p. 2545-2552. [CrossRef]

LAVERMICOCCA, Paola; VALERIO, Francesca; EVIDENTE, Antonio; LAZZARONI, Silvia; CORSETTI, Aldo and GOBBETTI, Marco. Purification and characterization of novel antifungal compounds from the sourdough Lactobacillus plantarum strain 21B. Applied and Environmental Microbiology, September 2000, vol. 66, no. 9, p. 4084-4090. [CrossRef]

LAVERMICOCCA, Paola; VALERIO, Francesca and VISCONTI, Angelo. Antifungal activity of phenyllactic acid against molds isolated from bakery products. Applied and Environmental Microbiology, January 2003, vol. 69, no. 1, p. 634-640. [CrossRef]

LI, Xiangfeng; JIANG, Bo and PAN, Beilei. Biotransformation of phenylpyruvic acid to phenyllactic acid by growing and resting cells of a Lactobacillus sp. Biotechnology Letters, April 2007, vol. 29, no. 4, p. 593-597. [CrossRef]

MAGNUSSON, Jesper and SCHNÜRER, Johan. Lactobacillus coryniformis sup. coryniformis strain Si3 produces a broad-spectrum proteinaceous antifungal compound. Applied and Environmental Microbiology, January 2001, vol. 67, no. 1, p. 1-5. [CrossRef]

MAGNUSSON, Jesper; STRÖM, Katrin; ROOS, Stefan; SJÖGREN, Jörgen and SCHNÜRER, Johan. Broad and complex antifungal activity among environmental isolates of lactic acid bacteria. FEMS Microbiology Letters, February 2003, vol. 219, no. 1, p. 129-135. [CrossRef]

MARTY-TEYSSET, C.; DE LA TOORRE, F. and GAREL, J.R. Increased production of hydrogen peroxide by Lactobacillus delbrueckii subsp. bulgaricus upon aeration: involvement of an NADH oxidase in oxidative stress. Applied Environmental Microbiology, January 2000, vol. 66, no. 1, p. 262-267. [CrossRef]

MESSENS, Winy and VUYST, Luc De. Inhibitory substances produced by lactobacilli isolated from sourdoughs, a review. International Journal of Food Microbiology, January 2002, vol. 72, no. 1-2, p. 31-43. [CrossRef]

MOLIN, Göran. Probiotics in foods not containing milk or milk constituents, with special refernce to Lactobacillus plantarum 299v1, 2, 3. American Journal of Clinical Nutrition, February 2001, vol. 73, no. 2, p. 380S-385s. [CrossRef]

NAGAO, Fumiko; NAKAYAMA, Masafumi; MUTO, Takashi and OKUMURA, Ko. Effects of a fermented milk drink containing Lactobacillus casei strain Shirota on the immune system in healthy human subjects. Bioscience Biotechnology and Biochemistry, 2000, vol. 64, no. 12 , p. $2706-2708$.

OUWEHAND, Arthur. Weight management: any role for probiotics? In: The $5^{\text {th }}$ Asian Conference on Lactic Acid Bacteria: Microbes in Disease Prevention \& Treatment, $1^{\text {st }}-3^{\text {rd }}$ July 2009, Singapore, p. 75.

PRACHYAKIJ, Pakorn; SCHNURE, Johan; CHARERNJIRATRAGUL, Wilawan and KANTACHOTE, Duangporn. Selection and identification of lactic acid bacteria that inhibit yeast contaminants isolated from fermented plant beverages. Songklanakarin Journal of Science and Technology, May 2007, vol. 29, sup. 2, p. 211-218.

PRACHYAKIJ, Pakorn; CHARERNJIRATRAGUL, Wilawan and KANTACHOTE, Duangporn. Improvement in the quality of a fermented seaweed beverage using an antiyeast starter of Lactobacillus plantarum DW3 and partial sterilization. World Journal of Microbiology and Biotechnology, September 2008, vol. 24, no. 9, p. 1713-1720. [CrossRef]

QIN, H.L.; ZHENG, J.J.; TONG, D.N.; CHEN, W.X.; FAN, X.B.; HANG, X.M. and JIANG, Y.Q. Effect of Lactobacillus plantarum enteral feeding on the gut permeability and septic 
complications in the patients with acute pancreatitis. European Journal of Clinical Nutrition, June 2007, vol. 62, no. 7, p. 923-930. [CrossRef]

REID, Gregor. The scientific basis for probiotic strains of Lactobacillus, mini-review. Applied and Environmental Microbiology, September 1999, vol. 65, no. 9, p. 3763-3766.

SALMINEN, Seppo. Clinical effects of probiotics in allergy prevention and obesity. In: The $5^{\text {th }}$ Asian Conference on Lactic Acid Bacteria: Microbes in Disease Prevention \& Treatment, $1^{\text {st }}-3^{\text {rd }}$ July 2009 , Singapore, p. 73-74.

SCHILLINGER, U. and LUCKE, F.K. Antibacterial activity of Lactobacillus sake isolated from meat. Applied and Environmental Microbiology, August 1989, vol. 55, no. 8, p. 1901-1906.

SHAH, N.P.; ALI, J.F. and RAVULA, R.R. Population of Lactobacillus acidophilus, Bifidobacterium spp. and Lactobacillus casei in commercial fermented milk products. Bioscience and Microflora, 2000, vol. 19, no. 1, p. 35-39.

ŞIMŞEK, Ömer; ÇON, Ahmet Hilmi and TULUMOG'LU, Şener. Isolating lactic starter cultures with antimicrobial activityfor sourdough processes. Food Control, April 2006, vol. 17, no. 4, p. 263-270. [CrossRef]

STROM, Katrin; SJOGREN, Jörgen; BROBERG, Anders and SCHNURER, Johan. Lactobacillus plantarum MiLAB 393 produces the antifungal cyclic dipeptides cyclo (L-Phe-L-Pro) and cyclo (L-Phe-trans-4-OH-L-Pro) and 3-phenyllactic acid. Applied and Environmental Microbiology, September 2002, vol. 68, no. 9, p. 4322-4327. [CrossRef]

TAMANG, Jyoti Prakash; TAMANG, Buddhiman; SCHILLINGER, Ulrich; GUIGAS, Claudia and HOLZAPFEL, Wilhelm $\mathrm{H}$. Functional properties of lactic acid bacteria isolated from ethnic fermented vegetables of the Himalayas. International Journal of Food Microbiology, September 2009, vol. 135, no. 1, p. 28-33.

THARMARAJ, Nalayini and SHAH, Nagendra P. Antimicrobial effects of probiotic bacteria against selected species of yeasts and moulds in cheese-based dips. International Journal of Food Science \& Technology, October 2009, vol. 44, no. 10, p. 1916-1926. [CrossRef]

VINDEROLA, C.G. and REINHEIMER, J.A. Lactic acid starter and probiotic bacteria: a comparative "in vitro" study of probiotic characteristics and biological barrier resistance. Food Research International, 2003, vol. 36, no. 9-10, p. 895-904. [CrossRef]

WILLKE, T. and VORLOP, K.D. Industrial bioconversion of renewable resources as an alternative to conventional chemistry. Applied Microbiology and Biotechnology, December 2004, vol. 66, no. 2, p. 131-142. [CrossRef]

WOLD, A.E. Role of bacterial adherence in the establishment of the normal intestinal microflora. In: HANSON, Lars A. and YOLKEN, Robert H. eds. Probiotics, other nutritional factors, and intestinal microflora. Philadelphia, Lippncott-Raven, 2002, p. 47-62.

ZHOU, J.S.; SHU, Q.; RUTHERFURD, K.J.; PRASAD, J.; GOPAL, P.K. and GILL, H.S. Acute oral toxicity and bacterial translocation studied on potentially probiotic strains of lactic acid bacteria. Food and Chemical Toxicology, February 2000, vol. 38, no. 2-3, p. 153-161. [CrossRef]

\section{How to cite this article:}

KANTACHOTE, D.; PRACHYAKIJ, P.; CHARERNJIRATRAKUL, W.; ONGSAKUL, M.; DUANGJITCHAROEN, Y.; CHAIYASUT, C.; NITODA, T. and KANZAKI, $\mathrm{H}$. Characterization of the antiyeast compound and probiotic properties of a starter Lactobacillus plantarum DW3 for possible use in fermented plant beverages. Electronic Journal of Biotechnology, September 2010, vol. 13, no. 5. http://dx.doi.org/10.2225/vol13issue5-fulltext-1 